\title{
René Girard a teorie mimetické rivality
}

\author{
Ivo Budil \\ Katedra antropologických a historických věd Fakulty filozofické Západočeské univerzity v Plzni, Tylova 18, 306 14 Plzeň
}

\section{RENÉ GIRARD AND THE THEORY OF MIMETIC RIVALRY}

\begin{abstract}
ABSTRAKCT René Girard proposed a theory of mimetic rivalry to explain the origin and internal consistency of human culture by the ritual breaking of a vicious circle of reciprocal violence through sacrifice of a scapegoat. Girard supposed that human relations are essentially based on imitations and competitions. Social coexistence was maintained, reconciliation was achieved and violence was replaced by a circle of ritual killings as a foundation of religious and cultural order. Girard's approach was influenced by Sigmund Freud and his work Totem and taboo and Émile Durkheim and his social explanation of religious life. The relationship of Girard's view to the theory of Merlin Donald on the three stages in the evolution of culture and cognition could be discussed. Girard is convinced that Christianity presented a historical attempt to demonstrate an innocence of victims of traditional scapegoating.
\end{abstract}

KEY WORDS mimesis; sacrifice; ritual; scapegoat; violence

ABSTRAKT René Girard je autorem teorie mimetické rivality, která se snaží vysvětlit původ a vnitřní soudržnost lidské kultury rituálním rozbitím bludného kruhu vzájemného násilí prostřednictvím usmrcení obětního beránka. Girard je přesvědčen, že lidské vztahy jsou primárně založeny na imitaci a soutěživosti. Společenské soužití bylo udržováno, usmíření bylo dosaženo a násilí sublimováno na základě pravidelně se opakujícího rituálního zabíjení, které položilo základy náboženského a kulturního řádu. Dílo René Girarda bylo ovlivněno Sigmundem Freudem a jeho studií Totem a tabu a Émilem Durkheimem a jeho sociálním výkladem náboženského života. Je třeba diskutovat vztah Girardových tezí k teorii Merlina Donalda o třech stadiích evoluce kultury a lidských kognitivních dispozic. Girard se domnívá, že křestanství představovalo historický pokus prokázat nevinu obětí rituálního násilí.

KLÍČOVÁ SLOVA mimeze; obět; rituál; obětní beránek; násilí

Gilbert Keith Chesterton kdysi napsal, že jedinec, který vymyslí teorii a poté vidí ve všem její důkaz, je největším nepřítelem lidského rozumu. Musím se přiznat, že při četbě Girardových textů jsem si na výše zmíněný výrok často vzpomněl, protože jde o autora, který na základě poměrně jednoduchého mechanismu vybudoval velmi rozsáhlou a ambiciózní antropologickou teorii, která se snaží vysvětlit téměř všechny aspekty lidské sociální, kulturní a historické existence. V tomto smyslu je francouzský historik, literární kritik a filozof sociálních věd René Girard redukcionista par excellence.

René Girard má řadu obdivovatelů, z nichž někteří jej - slovy Michela Serrese - pokládají za „Charlese Darwina věd o člověku“ (Girard 2004, 14; 2008, 10). S jeho dílem bylo před několika desetiletími spojováno značné očekávání. Když v roce 1972 vyšla pravděpodobně nejznámější Girardova kniha Násilí a posvátno, list Le Monde napsal, že „rok 1972 by měl být v análech humanitních věd označen hvězdičkou" (Kirwan 2008,
9). Filozof Paul Dumouchel uvedl, že „René Girard zcela změnil společenskovědní scénu, od literární kritiky až po obecnou teorii kultury, od vysvětlení úlohy náboženství v primitivních společnostech až po radikální reinterpretaci křestanství. Jeho počin vedl k explicitní mobilizaci etnologie, dějin náboženství, filozofie, psychoanalýzy a literární kritiky. Teologie, ekonomie, politologie, historiografie i sociologie - stručně řečeno všechny společenské vědy i vědy, které se kdysi označovaly jako vědy morální - jsou jím ovlivněny" (cit. Kirwan 2008, 9).

Přesto je dnes Girardova pozice v současném antropologickém myšlení - jak sám přiznává - spíše okrajová. Má samozřejmě své žáky a následovníky a inspiroval řadu dalších autorů. James Williams vydal Girard Reader (1996), Wolfgang Palaver shrnul girardovskou problematiku v knize René Girards mimetische Theorie (2003), pravidelně se koná girardovské Kolokvium o násilí a náboženství (Colloquium on Violence and Religion). K Girardovu odkazu se hlásí generativní antro- 
pologie, jejímž zakladatelem byl Girardův žák Eric Gans a která je rozvíjena zejména na stránkách internetového periodika Antropoetika. V teologických kruzích René Girard spolupracoval se skupinou badatelů soustředěných kolem Raymunda Schwagera, působícího na Innsbrucké univerzitě. V českém jazyce vyšla Girardova klasická práce Obětní beránek (1997), kniha rozhovorů $O$ původu kultury (2008) a stručná studie Michaela Kirwana René Girard: Uvedení do díla (2008). Girardovi se nicméně nepodařilo ovlivnit hlavní proud antropologických věd a vytvořit nové paradigma. Prorokovaná girardovská revoluce nenastala.

Ve věku oborové specializace působí šíre Girardovy aspirace a záběru až provokativně. Na základě poznatků vytěžených původně ze studia literatury vytvořil antropologickou teorii náboženství jdoucí proti téměř všem dominantním směrům poválečných věd o člověku, teorii, která se snaží nejenom vysvětlit vznik a reprodukci lidské kultury, ale rovněž poskytnout nový pohled na dějiny náboženství a v zásadě i rehabilitovat v naší sekulární a postmoderní společnosti význam křestanství (Girard 1978, 31-32). Současné akademické prostředí není prríliš vstřícné vưči autorovi, který spojuje literární studia $s$ antropologií a teologií a jehož mnohé závěry náležejí spíše do žánru náboženských vizí než odborného diskurzu. René Girard si byl tohoto svého odcizení od současné podoby sociálních disciplín vědom a neskrýval, že velká literární díla pokládá za spolehlivějšího průvodce na cestě $\mathrm{k}$ pravdě o člověku než dnešní humanitní a společenské vědy (Savage 1983, 711; Kirwan 2008, 47). Sociálním vědám rovněž vyčítá, že nebyly schopny navzdory veškerému úsilí vytvořit obecnou teorii kulturního vývoje (Girard 2004, 145; 2008, 108).

René Girarda tak můžeme srovnávat s kdysi oblíbeným paleontologem a katolickým knězem Pierrem Teilhardem de Chardinem (1881-1955), s jehož religiózně kosmologickými tezemi jej ovšem nespojuje prakticky nic. Pierre Teilhard de Chardin je dnes téměř zapomenut a my se musíme tázat, zda podobný úděl nečeká rovněž René Girarda. Girardovy práce lze dnes snadno nalézt prakticky v každém francouzském univerzitním knihkupectví, jejich autor však nepatří mezi myslitele, o jejichž odkazu by se vedly intenzivní diskuze. Navíc po 11. záŕí 2001 byl některými strážci politické korektnosti $\mathrm{v}$ důsledku svého kladného postoje ke křestanství a relativně kritickým či ambivalentním vztahem $\mathrm{k}$ islámu pasován téměř na náboženského fundamentalistu (Girard - Tincq - Hilde, 2002, 22-26).

René Girard se narodil v roce 1923 v Avignonu, kde jeho otec působil jako kustod avignonské knihovny a muzea a později Papežského paláce. Za druhé světové války vystudoval na École des chartes (Vysoké škole archivářské v Paříži) archivnictví a paleografii; roku 1947 obhájil dizertační práci Soukromý život v Avignonu ve druhé polovině patnáctého století. V témže roce využil Girard nabídky místa asistenta francouzského jazyka a literatury a odcestoval do Spojených států amerických. S touto zemí spojil celou svou životní dráhu. Působil na univerzitě v Indianě, kde v roce 1950 obhájil druhou disertační práci Lopinion américaine et la France 1940-1943, Duke University, Bryn Mawr College a v letech 1961 až 1968 přednášel jako profesor literatury na Johns Hopkins University v Baltimoru. Poté přešel na State University v New Yorku, následovala čtyři léta strávená opět na Johns Hopkins University a konečně od roku 1980 působil až do svého penzionování v roce 1995 na Stanfordské univerzitě v Kalifornii (Kirwan 2008, 14-15).

V roce 1966 byl René Girard jedním z organizátorů sympozia zvaného Řeč kritiky a humanitní vědy, kterého se zúčastnili mimo jiné Roland Barthes, Jacques Derrida a Jacques Lacan. Zmíněné setkání uvedlo na americkou akademickou půdu francouzské poststrukturalistické a dekonstruktivistické směry s trvalými důsledky pro místní univerzitní kulturu. Girard později prohlásil, že zmíněné směry přinesly do Ameriky mor (Girard 2004, 41; 2008, 31). Jeho podíl na zmíněném sympoziu byl poněkud paradoxní, protože ve svém vlastním učení se od uvedené postmoderní inspirace velmi výrazně odklonil, i když kritické vyrovnávání s Derridovou filozofií mělo pro jeho vlastní intelektuální vývoj zásadní význam (Girard 1978, 47).

René Girard navázal na teze sociologů a antropologů z přelomu devatenáctého a dvacátého století, např́iklad Williama Robertsona Smithe a Émila Durkheima, podle kterých hlavní funkcí náboženství v tradičních a archaických společnostech je udržovat sociální soudržnost především prostřednictvím kolektivně sdíleného rituálu (Girard 1978, 35-36; Kirwan 2008, 6). Antropolog Arthur Maurice Hocart v tomto smyslu napsal, že „horlivost pro určitý obřad je pevnějším tmelem než ekonomické ambice, protože rituál je spojen s morálními pravidly, zatímco ekonomie má za pravidlo zisk, který rozděluje, místo aby sjednocoval“" (cit. Girard 2004, 84; 2008, 64).

René Girard vyšel - obdobně jako řada dalších autorů z Aristotelovy poznámky v Poetice (48b, 6-7), že „člověk se od ostatních živočichủ liši tím, že má největši sklon napodobovat" (Girard 2004, 9; 2008, 7). Lidskou schopnost nápodoby však pojal v nejširším antropologickém a sociálním významu a vybudoval na jejím základě celou svoji antropologickou teorii, kterou nazývá mimetickou. Girard není samozřejmě ani prvním ani posledním autorem, který zdůraznil význam mimetismu čili nápodoby pro lidskou sociální a kulturní existenci a proces hominizace obecně. Např́iklad kanadský psycholog Merlin Donald, na kterého se sám Girard občas odvolával, vymezil ve své knize Origins of the Modern Mind (1991) v průběhu lidské evoluce tři odlišné kultury, odrážející různé stupně vývoje kognitivních schopností našich předků. Takzvaná epizodická kultura charakterizuje mentální úroveň dnešních lidoopů, kteří žijí v prrítomnosti pojímané jako série konkrétních epizod (Donald 1991, 124-161). Jejich pozoruhodné výkony při výuce znakové řeči hluchoněmých odhalili manželé Gardnerovi a Primackovi. Jakýmsi „chybějícím“ evolučním článkem mezi epizodickou kulturou, charakteristickou pro lidoopy a některé fosilní primáty, a lingvistickou (symbolickou) kulturou Homo sapiens byla podle Merlina Donalda mimetická kultura, která představovala první specificky lidskou, ale současně nelingvistickou kulturu. Jejími tvůrci byly populace řazené souhrnně a nepříliš přesně do jednotné kategorie Homo erectus. Mimetická kultura, která se vyznačo- 
vala neobyčejnou konzervativností, připomínala $\mathrm{v}$ mnohém komunikaci lidoopů, obsahovala údajně všechny lidské vlastnosti prokazatelné u současných jedinců postižených ztrátou jazykové kompetence. Na rozdíl od lingvistických center, jež jsou umístěna $\mathrm{v}$ levé hemisféře, jsou mimetické kompetence spjaty s pravou hemisférou mozku. Mimetická kultura se vyznačovala ikonickou (nesymbolickou) povahou, kterou můžeme pozorovat např́iklad v pantomimě. Mezi významné inovace mimetické kultury náležel smysl pro rytmus a melodické a harmonické aspekty prozódie. Mimetická gesta, včetně faciální exprese, hrají významnou úlohu při dorozumívání, avšak označit tento zpo̊sob komunikace za „prajazyk“ nebo „protojazyk" by bylo zavádějící, protože je podmíněn odlišným neurologickým substrátem. Výrazy tváře představují v lidské ontogenezi první formu komunikace s okolím, předcházející rozvoj jazyka. Mimetická kultura představovala vhodné prostředí pro vytvoření pozdější lingvistické kultury. Mimetické prostředky, včetně gest, výrazu tváře, intonace a ostatních složek prozódie, mají výraznou "metalingvistickou“ funkci a umožňují sémantickou interpretaci mnohoznačných výroků. Merlin Donald zdůraznil, že mimetická kultura vedla ke vzniku prvního, kolektivně sdíleného modelu reality, jenž byl zprostř̌edkován nikoliv jazykově, nýbrž rituálně, a ustavila rituální praktiky, tance, hry a složitější technologii. Mimetismus je důležitým médiem kulturního přenosu (Donald 1991, 162-200).

Merlin Donald, inspirovaný holistickou tradicí, razí názor, že hlavním smyslem lingvistické adaptace nebylo vytvoření jazyka, ale spíše vznik integrálního, souvislého, původně mytického myšlení, poskytujícího celistvý obraz světa. Jazyk posloužil pouze jako nutný prostředek $\mathrm{k}$ dosažení tohoto cíle. Člověk se liší od lidoopů úrovní mentálních modelů, které je jeho mysl schopna vytvářet. Jedním $\mathrm{z}$ projevů této výlučnosti lidského myšlení je schopnost vyprávění, narativita, zakládající koherentní, kulturní vizi skutečnosti. Symbolická lidská kultura, rozšířená migrací anatomicky moderního Homo sapiens sapiens po celé planetě, představuje komplex složený $\mathrm{z}$ aspektů epizodických, mimetických a lingvistických, které reprezentují odlišná stadia evoluce lidské mysli. Tyto jednotlivé typy semiotických mentálních modelů jsou integrovány a zastřrešeny vyprávěním (narativitou), nejvyšším výkonem vědomí našeho druhu (Donald 1991, 201-268).

Dílo René Girarda můžeme charakterizovat jako pokus ukázat, že navzdory našim lingvistickým schopnostem nejsou mimetické dispozice anachronismem, ale představují nadále klíčový a vitální faktor stojící u zrodu našeho kulturního života a umožňující jeho reprodukci. Mimetismus může sehrávat rovněž důležitou úlohu v procesu, který Dan Sperber nazval „epidemiologií reprezentace“ (Sperber 1996, 56-76).

Proti jiným teoretikům, kteří chápou mimetismus převážně jako ikonický systém gest, Girard zdůraznil, že také lidská touha má mimetickou povahu (Girard 1977). Této problematice se věnoval již ve své prvotině Lež romantismu a pravda románu z roku 1959, v níž se zabýval pěti velkými evropskými romanopisci (Cervantesem, Flaubertem, Stendhalem, Proustem a Dostojevským), kteří všichni prošli v průběhu svého ži- vota jistým osvobozujícím obratem, „konverzi“', jež jim umožnila vytvořit jejich nejvýznamnější díla (Kirwan 2008, 8-9). Tato „konverze“ spočívala právě v uvědomění si mimetického charakteru lidské touhy (Kirwan 2008, 9). René Girard postavil do protikladu romantismus a román. „Lež romantismu“ spočívá v iluzi o údajné autonomii a stálosti naší touhy vyplývající $z$ naší autentické povahy. Román ve svých vrcholných podobách ukazuje, že veškerá naše touha je odvozená, je to pouhá imitace, napodobenina touhy druhých. Naše touha se vždy rodí z nápodoby touhy někoho jiného, koho pokládáme za vzor. Toužíme po něčem, protože po tom touží jiní, to znamená, že nemáme žádnou autonomní, nezávislou touhu, jak se nám snažila namluvit tradice romantismu. Např́íklad Don Quijote odvozoval své touhy po dobrodružném a ctnostném životě podle legendárního rytíre Amadise Galského. Don Quijote si tak svou idealistickou touhu vypůjčil od vybájené postavy, jejímž dvojníkem se tímto de facto stal (Girard 1968, 9-10). Španělský snílek mohl existovat pouze prostřednictvím své neustálé imitace bájného rytíře Amadise Galského a obdobně náš subjekt, naše já, je „nestabilní, neustálou proměnlivou a prchavou strukturou“, která existuje pouze díky touze (Kirwan 2008, 25).

René Girard je dokonce přesvědčen, že mimetické přisvojení touhy druhého člověka nahradilo instinktivní chování v roli hlavního určujícího faktoru lidského jednání (Kirwan 2008, 25). Podle Girarda jsou lidé náchylnější k vzájemným vražedným konfliktům mnohem více než ostatní živočichové, protože postrádají instinktivní „brzdné“ mechanismy bránící eskalaci násilí (Girard 1978, 32-33; Kirwan 2008, 25).

Napodobování druhých je obvyklé u dětí, vyskytuje se však rovněž u dospělých, kteří se nicméně za imitaci jiných lidí stydí a skrývají ji, protože se obávají, že tím odhalují nedostatečnost a slabost své vlastní existence (Kirwan 2008, 25-26). Pokud lidé touží po stejném objektu, nastává rivalita, která ústí do otevřeného konfliktu. Zde však musíme rozlišovat. Mezi Donem Quijotem a Amadisem nemůže dojít ke střetu, protože Amadis Galský je pouhou ideální fiktivní postavou; mezi ním a Donem Quijotem je nepřekročitelná propast bránící soupeření (Kirwan 2008, 31). Obdobně nenastane rivalita mezi Donem Quijotem a Sancho Panzou, protože Sancho Panza uznává své hierarchicky podřízené postavení (Kirwan 2008, 31). René Girard nazývá tuto „bezpečnou formu napodobování či miméze“ „vnějším zprostředkováním“ nebo „Vnější mimézi“" (Kirwan 2008, 31). Mezi křestany a Kristem, kterého veřrící napodobovali v duchu imitatio Christi, nemohla nikdy nastat mimetická rivalita.

„Vnitřní zprostředkování“ či „vnitřní miméze“ znamená, že mimetická touha spojuje reálné osoby pohybující se ve stejném sociálním prostoru. Jestliže společnost nedokáže stanovit hierarchii mezi toužícím subjektem a jeho vzory, hrozí vypuknutí eskalujícího konfliktu v podobě rivalizujícího mimetismu mezi vzorem a subjektem o získání objektu jejich společné touhy (Girard 2004, 10; 2008, 7; Chow 2006, 142-143). Tento střet připomínající Hobbesovu „válku všech proti všem“ může v krajním př́padě vyústit do hromadného násilí prakticky znemožňujícího společenský život jako takový (Girard 1978, 
33). Za př́klad mohou posloužit hrdinové Dostojevského románů stravovaní, frustrovaní a pohlcovaní destruktivní mimetickou rivalitou. V období mezi Cervantesem a Dostojevským došlo v Evropě k rušení hierarchických rozdílů, což se projevilo v růstu mimetické rivality, které se staví do cesty stále méně bariér (Kirwan 2008, 35). Mimetická rivalita a násilí působí jako nakažlivá nemoc a podle Girarda mytická svědectví o morových epidemiích, egyptských ranách nebo potopě jsou často skrytými svědectvími o eskalující mimetické krizi rozvracející společnost (Kirwan 2008, 53). Na druhé straně, jak podle Girarda ukázali někteří velcí spisovatelé jako William Shakespeare, Stendhal nebo Gustave Flaubert, lze dosáhnout obrácení či osvobození spočívající v tom, že si uvědomíme, že „jsme odjakživa nevědomky napodobovali špatné vzory, které nás stahují do začarovaného kruhu pohoršení a nikdy neukojitelných tužeb“ (Girard, René, 2004, 138; 2008, 104).

Girardova teze o důležitosti uspokojení mimetické touhy je inspirována Hegelovým pojetím touhy po uznání (Anerkennung), které reinterpretoval a proslavil na svých pařižských přednáškách v letech 1933 až 1939 Alexander Kojève (Kirwan 2008, 37). Mezi myslitele ovlivněné Kojèvovou interpretací náleželi např́klad Hannah Arendtová, George Bataille, Maurice Merleau-Ponty a Jacques Lacan a ze současných autorů se jej dovolává např́klad Francis Fukuyama. Touha člověka po uznání je natolik silná, že riskuje v zápase svůj biologický život, aby uspokojil svoji nebiologickou touhu (Kirwan 2008, 38).

Problematika mimetické rivality nás přivádí na půdu vnitroskupinového násilí, která představuje podle Girarda největší riziko pro sociální soudržnost a přežití. Girard zásadně nesouhlasí se slavnou tezí Thomase Hobbese, že lidé pohroužení do vzájemného nepřátelství si v okamžiku, kdy konflikt vrcholí, uvědomí, že je třeba skoncovat s rivalitou a podřídit se všemohoucí omezující síle, kterou Hobbes nazval Leviatanem (Kirwan 2008, 52-53). Myšlenku, že lékem na pandemické násilí je společenská smlouva, pokládá René Girard za naivní. Dlouhotrvající konflikt tlumí v aktérech schopnost vidět v soupeři lidskou bytost a tato démonizace nás zbavuje i empatie omezující míru spáchaného násilí (Kirwan 2008, 55). Doufat v této situaci v náhlé přerušení násilí a uzavření společenské smlouvy je iluze. Jak tedy zastavit eskalující mimetickou rivalitu?

René Girard se výrazně inspiroval proslulou Freudovou prací Totem a tabu (Totem und Tabu, Über einige Übereinstimmungen im Seelenleben der Wilden und Neurotiker) z roku 1913 (Girard 1978, 44; Chow 2006, 143). Jak známo, zakladatele psychoanalýzy podnítila $\mathrm{k}$ zájmu o prehistorii lidstva studie jeho žáka a pozdějšího soupeře Carla Gustava Junga Metamorfózy a symboly libida vydaná v roce 1911. Freud přečetl Frazerova díla Zlatá ratolest a Totemismus a exogamie, Čtení o náboženství Semitů od Williama Robertsona Smithe a spisy Edwarda Burnetta Tylora a Andrewa Langa. Skotský teolog a antropolog William Robertson Smith popisoval rituál totemismu jako obřad, při kterém bylo posvátné totemové zvíře zabito, snědeno a nakonec oplakáváno. Po této proceduře následovala slavnost, vrcholící očistnou katarzí. Sigmund Freud rovněž souhlasil s vizí darwinisty Jamese Atkinsona, jenž vylíčil společenský život pravěkých lidí jako nadvládu tyranského samce nad tlupou složenou $\mathrm{z}$ podmaněných samic a jeho potomků. Podle Freuda se synové despotického samce spojili a zabili a snědli svého otce. Nedohodli se však při dělení žen, a jejich soudržnost byla proto ohrožena. Ztotožnění otce $s$ totemovým zvířetem - předkem - a jeho rituální pojídání mělo navždy zabránit otcovraždě - patricidě. Zároveň byl zaveden zákaz incestu a prosadila se exogamie. Tímto způsobem byl ustaven univerzální náboženský rituál, od kterého se podle Freuda odvozují základní sociální organizace a mravní imperativy lidstva včetně koncepce dědičného hříchu (Budil 2003, 232-233).

Girard se pochopitelně nedomnívá, že by mohla existovat jediná pravěká událost ovlivňující celé následující dějiny lidstva. Zároveň je však přesvědčen, že prvotní funkcí náboženství a rituálu je regulace násilí (Girard - Goodhart, 1977; Girard 1977; Girard 1984). Ve své zásadní studii Násilí a posvátno ( $L a$ violence et le sacré, 1972) René Girard uvedl, že násilí je srdcem a skrytou duší posvátna (Kirwan 2008, 49).

Pravěká společnost byla podle Girarda prostoupena mimetickou rivalitou a existenčními problémy, které ohrožovaly její samotnou existenci. Proto bylo zapotřebí nasměrovat kolektivní násilí proti určitému jedinci, jenž byl učiněn odpovědným za danou sociální krizi. Dosavadní rivalové se spojili za účelem jeho likvidace a tento akt obětního násilí se stal momentem obnovení jejich společenské soudržnosti. Zmíněná pravěká událost byla ritualizována a stala se základem pro vznik a rozvoj lidské kultury, institucí, tabu a norem. Proceduru vytvořenou za účelem usměrnění a kontroly násilí uvnitř skupiny nazývá René Girard rituálem obětního beránka. Naše instituce včetně všech etických norem se zrodily z mechanismu obětního beránka jako krajního řešení kolektivního násilí vyplývajícího z mimetické rivality (Girard 2004, 10-11; 2008, 8): „Lidský ř́d jakožto protiklad řádu zvírecího, jenž mu předcházel, se stává závislým na posvátnu, jež je definováno jeho vlastním násilím; jsme jediným druhem, pro nějž mimetické násilí představuje větši hrozbu než vnější prrírodni svět představovaný ostatními druhy" (Kirwan 2008, 110-111). Volba obětního beránka není úplně nahodilá; vesměs jde o osobu, která se svým vzhledem či jednáním odlišuje od ostatních, je sociálně izolovaná a vyznačuje se takzvanými perzekučními stereotypy, které ji činí zranitelnou. Starý zákon popisuje „preferenční znaky obětní selekce následovně“: „(...) nemél vzhled ani di̊stojnost. Viděli jsme ho, ale byl tak nevzhledný, že jsme po něm nedychtili. Byl v opovržení, kdekdo se ho zřekl, muž plnýbolesti, zkoušený nemocemi, jako ten, před nímž si člověk zakryje tvár̆, tak opovržený, že jsme si ho nevážili“ (Iz 53,2-3). Aby byl rituál účinný, musí být všichni účastníci obřadu a rituální vraždy přesvědčeni o nezpochybnitelné vině oběti a komunita musí sama před sebou zatajit pravou podstatu toho, co činí (Kirwan 2008, 71). Současně je třeba nevzpomínat na akt usmrcení vybraného jedince jakožto na násilnou vraždu, ale jako na obět', která přinesla danému společenství mír a soulad a stala se součástí náboženského obřadu. Toto napětí mezi skutečnou povahou činu, jehož pů- 
vodní podoba stále prosvítá skrze zkreslující mytickou tradici, a jeho pozdější sakrální interpretací je patrné zejména $\mathrm{v}$ antických tragédiích, kterým dodává svébytnou metafyzickou hloubku: „Proč však musí hrdina tragédie trpět a co znamená jeho tragická vina? (...) Musí trpět, protože je praotcem, hrdinou oné pradávné velkotragédie, která se tu záměrně opakuje, a tragickou vinu musí vzít na sebe proto, aby chór zbavil viny. Scéna na jevišti vzešla ze scény historické záměrnè deformována, dalo by se řici: ve službách rafinovaného pokrytectví. Voné staré skutečnosti to byli právě členové chóru, kteří byli príčcinou hrdinova utrpení; v této scéně se však omezují na účast a lítost, hrdina si své utrpení zavinil sám. Zločin presunutý na hrdinu, velikášství a vzpoura proti mocné autoritě je totéž, co skličuje chór, bratry. Tak se tragický hrdina - zatím proti své vưli - stává spasitelem chóru“ (Freud 1991, 104, přeložil Ludvík Hošek). Jak napsal v knize Násilný původ (Violent Origins, 1987) Burton Mack, „kulturní artefakty jsou strukturovány tak, aby mechanismus násilí zakrývaly, a dokonce i samotný tento mechanismus je konstruován tak, aby sám sebe skryl " (cit. Kirwan 2008, 64).

Obětní beránek má proto ambivalentní povahu, je nenáviděn i posléze zbožštěn, je monstrem i primitivním bohem. René Girard je přesvědčen, že prvotní božstva se zrodila $\mathrm{z}$ obětních beránků, jejichž usmrcení zastavilo destruktivní mimetickou rivalitu a umožnilo zrod soudržného kulturního společenství. Jako důkaz mu slouží např́íklad líčení rozporuplné povahy řeckých bohů v podání Mircey Eliada: „Vynikají (héróové) silou a krásou, ale také obludnými rysy (obři vzrůst - Héráklés, Achilleus, Orestés, Pelops - ale také vzrůst nad obyčej zakrslý), jsou thériomorfní (např. Lykáón, „vlk“) nebo schopní promèňovat se ve zvírata. Jsou androgynní (Kekrops) nebo mèní pohlaví (Teiresiás), anebo se převlékaji za ženy (Héráklés). Kromě toho se héróové vyznačují četnými anomáliemi (bezhlavost nebo mnohohlavost; Hérákles má tř̀ řady zubů); zejména jsou kulhaví, jednoocí nebo slepí. Nejednou padají héróové za obět' šilenství (Orestés, Bellerofón, i výjimečný Héráklés, když vraždí syny, které mu dala Megara). Pokud jde o jejich sexuální chování, bývá výstřední nebo abnormální - Héráklés za jedinou noc oplodní padesát Thespiových dcer; Théseus je proslulý četnými znásilněními (Helené, Ariadné atd.), Achilleus unáši Stratoniku. Héróové se dopouštějí incestů se svými dcerami či matkami a vraždí se závistí, z hněvu a nejednou bez jakéhokoliv duvodu; umoři často i své otce, matky nebo príbuzné" (cit. Girard 1997, 44).

Vidíme, že jsme dosáhli sociálního míru potřebného k našemu kulturnímu vývoji za cenu násilného obětování nevinné oběti, přičemž veškerá mytologická, náboženská a rituální tradice se snaží tento prvotní zločin nikoliv ospravedlnit, nýbrž zamaskovat a zakrýt. Na rituál, který vznikl v kontextu mimetické kultury, jak ji vymezil Merlin Donald, navázala lingvistická kultura, jejímž plodem je mýtus jako celostní vyprávění. Mýtus ale pokračuje v konspiraci mlčení obklopující primordiální rituální vraždu. René Girard pojímá mýtus jako př́běh, který společenství vypráví o svém původu - naraci, v níž je násilná povaha tohoto původu nepřímo naznačena, avšak nikdy otevřeně odhalena: Mýtus pomáhá zachovávat mlčení o násilí páchaném na obětním beránkovi (Kirwan 2008, 71). V mýtu proto nehledejme podle vzoru romantiků jakousi symbolickou pravdu o autentických podmínkách a povaze lidské existence, protože mýtus je verbalizovaná a neustále reprodukovaná sociální lež zakrývající násilný počátek naši kultury. Nositelé mytické tradice na tuto původní funkci mýtu zakrývající primordiální vraždu, která se proměnila $\mathrm{v}$ rituál, již zapomněli, přičemž toto zapomnění má téměř charakter psychoanalytického potlačení traumatizujících událostí v našem individuálním životě. Výše zmíněnou problematiku René Girard rozpracoval především v knihách př́značně nazvaných Věci skryté od založení světa (Des choses cachées depuis la fondation du monde, 1978), Obětní beránek (Le Bouc émissaire, 1982) a Ten, skrze nějž přichází pohoršení (Celui par qui le scandale arrive, 2001).

René Girard se tak vypravil na velmi nejistou půdu spekulací o prehistorických událostech, jež před statisíci lety ustavily lidskou kulturu. Jde o oblast, kterou antropologové již dávno opustili a raději přenechali svobodné fantazii literátů, jako byl například William Golding, autor slavné novely Dědicové (Inheritors). René Girard se rovněž postavil proti dominantnímu proudu antropologického myšlení, jehož jedním vrcholem byla strukturální antropologie Clauda Lévi-Strausse (1908-2009) a které zavrhlo či marginalizovalo bádání o původu lidské kultury a institucí (Girard 1978, 38-43). Bylo proto poměrně jednoduché označit Girardovy teze za spekulace nepodložené prakticky žádnými empirickými důkazy či vytknout Girardovi, že se př́liš vzdálil dominantnímu antropologickému paradigmatu. Ze známějších autorů má k Girardovi intelektuálně blízko německý odborník na staré Řecko Walter Burkert, autor známé knihy Homo Necans (1972), který obdobně jako René Girard pokládal „akt zabití za definiční vlastnost lidského společenského byti“" (cit. Kirwan 2008, 112). Pro Waltera Burkerta je však primární obětí kořist zabíjená za účelem získání potravy, takže archaické mýty a rituály vyrůstají z loveckých obřadů, nikoliv ze zabíjení obětního beránka (Burkert 1985, 54-60; Dubuisson 1993, 310-311; Kirwan 2008, 112).

René Girard byl přesvědčen, že hlavním motivem domestikace zvírat nebyl ekonomický, ale rituální zájem: „Se zvíraty se začalo zacházet jako s lidskými bytostmi, aby mohla být obětována, príčemž by zviŕecí obèti nahradily oběti lidské" (Girard 2004, 170-177; 2008, 127). Takto se naprŕíklad Ainové v severním Japonsku pokusili neúspěšně z rituálních důvodů domestikovat lední medvědy (Girard 2004, 171; 2008, 128). Girard argumentuje, že hospodářské výhody nemohly být určující, protože dokud se neprojevily, nikdo by si je nedokázal představit (Girard 2004, 170-171; 2008, 127). V oblastech, kde neexistovala domácí zvírata, např́iklad v předkolumbovském Mexiku, rituální zabíjení lidí neustalo (Girard 2004, 171; 2008 , 127). Podle Girarda od doby, kdy zanikly zvírecí oběti, nebyl již domestikován žádný další zvírecí druh: „Domestikace je lidská aktivita náboženského charakteru a nečekaný vedlejši produkt obětování zvírat. Lidská kultura i lidstvo samo jsou plody náboženských okolností ("La domestication est une entreprise humaine et religieuse, un sous-produit inattendu du 
sacrifice animal. La culture humaine et lhumanité elle-même sont filles du religieux") Girard 2004, 172; 2008, 128).

Dostáváme se nyní k Girardovu vztahu ke křestanství. Girard nikdy neskrýval, že je věřícím a že svou víru na rozdíl od jiných nijak neodděluje od svého literárně historického a antropologického bádání. René Girard citoval souhlasně Simone Weilovou, že evangelia jsou mnohem více "teorií o člověku“ než „teorií o Bohu“ (Girard 2004, 19; 2008, 14). Podle Girarda význam křest’anství spočívá $\mathrm{v}$ „kulturním a morálním uchopení skutečnosti, že povaha naši kultury a společnosti je spojena s obětí" (Girard 2004, 19; 2008, 14).

Podle Girarda pouze křestanství dokázalo na neustále se reprodukující a dějinami procházející usmrcení nevinného jedince $\mathrm{v}$ zájmu sociální soudržnosti reagovat alternativním př́během, v němž postavilo do středu děje osobu, která podlehla skupinové nenávisti, ale jejíž nevina byla nezpochybnitelně prokázána a zdůrazněna. Tím se zhroutila celá logika rituálu obětního beránka, byl plně demaskován jeho násilnický charakter, byly rehabilitovány předchozí oběti skupinového násilí a rituálně maskovaná vražda přestala být aktem ustavujícím kulturu: „Kristova obět predstavuje zlomový okamžik, kdy byla narušena rovnováha udržujicí symbolicko-náboženský mechanismus, na němž byly založeny nejstarší společnosti, ve stálosti, repetitivnosti a mytičnosti“ („Le sacrifice du Christ représente le moment de rupture de léquilibre qui maintenait stable, récurrent et mythique le mécanisme symbolique et religieux sur lequel se fondaient les sociétés archaïques") (Girard 2004, 19; 2008, 14). Křestanství jako první náboženství ukázalo obět jako obět a vraždu nazvalo vraždou. Kř̀estanství tak představuje pro Girarda klíčovou fázi antropologického vývoje, během něhož se člověk musel vyrovnávat se skupinovým násilím ohrožujícím jeho sociální soudržnost. Tradiční společnost byla nucena nacházet stále nové obětní beránky, kteří byli navzdory své nevinně usmrceni a prohlášeni za vinné. Její postoj lze shrnout Kaifášovým výrokem: „Lépe když zemře jeden, než aby zahynulo celé společenstvi“" (J 11,51). Proti tomuto archaickému postoji je postaveno Kristovo konstatování: „Nenáviděli mě bezdưvodně (J 15, 25). Křest’anství tak podle Girarda bylo pro kulturní vývoj lidstva tím, čím byla kultura pro přirozený výběr (kdy se člověk emancipoval od zákonitostí darwinovského přírodního výběru). Prostřednictvím křestanství se člověk osvobodil od nutnosti odstraňovat vnitřrní konflikty a krize uvnitř společenství obětováním obětních beránků, jejichž nevina, tradičně zastřena mýtem, byla jednoznačně demonstrována.

Můžeme pochopitelně namítnout, že dějiny křestanské civilizace, zahrnující protižidovské pogromy, inkviziční procesy či hony na čarodějnice, jasně ukazují, že mechanismus obětního beránka existuje i nadále a nijak nepozbyl své dynamiky a agresivity. Skupinová nenávist zaměřená proti nevinným obětem nezmizela, a naopak ve dvacátém století nabyla netušených rozměrů. Na tuto výhradu René Girard odpověděl následujícím zpo̊sobem: „Nevina oběti je zásadní výdobytek, a ten přineslo křestanství. Ale nikdy jsem neprosazoval zásadu, že onen proces je čistě lineární a že se od okamžiku Zjevení vyvijí nepretržitě. Naopak, je to proces mimořádně složitý, protože člověk si svou cestu volí svobodně. A po pravdě řečeno téměr pokaždé se rozhoduje pro násilí, dnes více než kdy jindy" (Girard 2004, 132-133; 2008, 100).

\section{LITERATURA}

Budil, Ivo (2003): Mýtus, jazyk a kulturní antropologie. Praha: Triton.

Burkert, Walter (1985): Greek Religion: Archaic and Classical. Oxford: Harvard University Press.

Donald, Merlin (1991): Origins of the Modern Mind. Three Stages in the Evolution of Culture and Cognition. Cambridge, MA: Harvard University Press.

Dubuisson, Daniel (1993): Mythologies du XX $X^{e}$ siècle. Lille: Presses Universitaires de Lille.

Freud, Sigmund (1991): Totem a tabu. Praha: Mladá fronta.

Girard, René (1968): Lež romantismu a pravda románu. Praha: Československý spisovatel.

Girard, René (1976): Superman in the Underground: Strategies of MadnessNietzsche, Wagner, and Dostoevsky. MLN, 91(91),1161-1185.

Girard, René (1977): Violence and Representation in the Mythical Text. $M L N$, 92(5), 922-944.

Girard, René (1978): Interview: René Girard. Diacritics, 8(1), 31-54.

Girard, René (1984): Dionysus versus the Crucified. MLN, 99(4), 816-835.

Girard, René (1997): Obětní beránek. Praha: Lidové noviny.

Girard, René (2004): Les origines de la culture. Paris: Hachette.

Girard, René (2008): O pưvodu kultury. Hovorys Pierpaolem Antonellem a Joãem Cezarem de Castro Rocha. Brno: Centrum pro studium demokracie a kultury.

Girard, René a Sandor Goodhart (1977): Dionysus and the Violent Genesis of the Sacred. Boundary 5(2), 487-506.

Girard, René - Tincq, Henri -Hilde, Thomas C. (2002): What Is Happening Today Is Mimetic Rivalry on a Global Scale. South Central Review, $19(2 / 3,9 / 11), 22-27$

Chow, Rey (2006): Sacrifice, Mimesis, and the Theorizing of Victimhood (A Speculative Essay). Representations, 94(Special Issue, Spring), 131149.

Kirwan, Michael (2008): René Girard: Uvedení do díla. Brno: Centrum pro studium demokracie a kultury.

Savage, Nadine Dormoy (1983): Conversation avec René Girard. The French Review, 56(5), 711-719.

Sperber, Dan (1996): Explaining Culture: A Naturalistic Approach. Oxford: Blackwell.

\section{AUTOR}

Budil, Ivo T. (8. 8. 1965, Praha), český antropolog; profesor a vedoucí Katedry antropologických a historických věd Fakulty filozofické Západočeské univerzity v Plzni a děkan této fakulty (v letech 1999-2005). Vystudoval Přírodovědeckou fakultu Univerzity Karlovy v Praze, disertační práci obhájil v roce 1994 na Filozofické fakultě Univerzity Karlovy, roku 2001 se habilitoval v oboru Sociologie na Fakultě sociálních věd Univerzity Karlovy a v roce 2006 jmenován profesorem v oboru Antropologie na Masarykově univerzitě v Brně. Působil na univerzitách v Aix-en-Provence, Lyonu a na Johns Hopkins University v Baltimoru. V letech 1996 až 1998 byl viceprezidentem mezinárodní organizace Language Origins Society a v roce 2002 byl na dva roky zvolen viceprezidentem Společnosti pro vědu a umění. Od roku 1998 stojí v čele Katedry sociální a kulturní antropologie Fakulty humanitních studií Západočeské univerzity v Plzni a nyní Katedry antropologických a historických věd Fakulty filozofické Západočeské univerzity v Plzni.

Kromě řady odborných studií a statí je autorem knih Mýtus, jazyk a kulturní antropologie (Praha: Triton, 1992, 1995, 1998, 2003), Za obzor Západu (Praha: Triton, 2001, 2007), Od prvotního jazyka 
k rase (Praha: Academia, 2002), Válka Zuluů: Britsko-zulská válka $v$ roce 1879 (Praha: Triton, 2006), Zakladatelé Západu a poslední člověk (Ústí nad Labem: Dryada, 2007) a Jitro Árijců: Život a dílo Arthura Gobineaua, zakladatele árijské ideologie (Praha: Triton, 2009). Původně se věnoval $\mathrm{v}$ rámci biologické antropologie problematice vzniku artikulované řeči a vývoje jazykové kompetence u fosilních předků moderního člověka, od počátku devadesátých let pak rovněž vybraným otázkám indoevropeistiky, především v oblasti srovnávacího náboženství. Od druhé poloviny devadesátých let se zabývá především konstituováním a proměnami moderního antropologického myšlení, otázkami kontaktů mezi různými kulturními a civilizačními okruhy, globalizace a modernizace. Pro edici Panoráma biologické a sociokulturní antropologie napsal 26. svazek Zrození moderní rasové teorie: Život a dílo Victora Courteta (2005). Je nositelem Ceny Josefa Hlávky za rok 2001 a laureátem Ceny zakladatele Antropologického ústavu prof. MUDr. et PhDr. Vojtěcha Suka, DrSc. (2009).

Kontakt: Prof. RNDr. Ivo Budil, Ph.D., DSc., Katedra antropologických a historických věd Fakulty filozofické Západočeské univerzity v Plzni, Tylova 18, 30614 Plzeň, e-mail: budil@ksa.zcu.cz. 
